\title{
樹脂モ一ルド構造における樹脂と金属間界面の疲労強度設計
}

\section{Design of fatigue strength on adhesive interface between metal and resin in Resin-molded structure}

\author{
Miki YAMAZAKI ${ }^{* 1}$ \\ ${ }^{*}$ Japan Hitachi, Ltd. Hitachi Research Laboratory \\ 832-2 Horiguchi, Hitachinaka-shi, Ibaraki 312-0034, Japan
}

Received 20 May 2014

\begin{abstract}
For the stabilization of insulation performance in the resin-molded insulators, strong adhesion between the resin and metal is required. In this paper, design method of fatigue strength on adhesive interface between metal and resin in consideration of multiple scales was investigated. Test pieces were made by covering $\mathrm{Cu}$ and SUS cylinders, which have some values of surface roughness, with epoxy resin. The interfacial strength was evaluated with shearing tests of these test pieces. The effective adhesive surfaces of those cylinders were evaluated from surface observation with a laser microscope. The interfacial strength increased with surface roughness and the adhesion-strength index $(\mu+\mathrm{B})$. The adhesion-strength index $(\mu+\mathrm{B})$, which had been proposed in previous paper, were calculated with the effective adhesive surface and the interfacial strength. The adhesion-strength index $(\mu+\mathrm{B})$ gave a constant value with various surface roughnesses for each metal. Based on the strength evaluations, the interfacial strength could be controlled, and it became clear from the results that the interfacial strength can be improved up to the confidence level. The results also show that design of the interfacial strength over multiple scales can help improve the reliability of electric power equipment.
\end{abstract}

Key words : Resin-molded structure, Adhesion-strength index, Fatigue strength, Interfacial strength, Surface roughnesses, Multiple scales

\section{1. 緒言}

一般的に製品設計は，構造物における全般的な変形，流体流動，熱伝達，電磁気現象を考慮した有限要素解析 (Finite Element Analysis，FEA)を用いた評価手法により，巨視的な領域(マクロスケール)において実施される場合 が多い，一方で，構造物に生じる現象を正確に把握するためには，物体内粒子あるいは原子単位の挙動を分析に よる分子動力学・量子力学に基づき微視的な領域(ナノスケール)における解析・評価が求められる。しかし，こ のナノスケールにおける解析は非常に小さいスケールでの挙動であり，マクロスケールにおける製品設計に直接 適用することは困難である，従って，微視的なモデリングと巨視的なモデリングの間の膨大な差分を処理するた めに，これらを連結し解析するマルチスケールを考慮した設計手法が必要である(山崎, 2013)。

たとえば，電力機器に幅広く用いる樹脂モールド構造(Okamoto, et al.,2003)，(Sato, et al.,2002)は，樹脂と金属や セラミクスなど異なる材料の組み合わせによって形成されるために，材料特性の違いにより樹脂層のクラックや 界面はく離が発生しやすい(Wong and Varral, 1994)，(Atkinson and Cicek, 1983a,1983b). これらの樹脂層のクラック や界面はく離が生じると界面における絶縁性能が低下寸る，絶縁性能が低下寸るのは，樹脂の硬化反応時の残椬 や樹脂に浸透していた空気や水分が空隙に出てきて絶縁性能の低い気体で充たされた状態となるためである。こ のような構造物における現象をマクロスケールにおける FEA による解析や実験で解明したとしても, 絶縁性能を 確保する構造を得ることは困難な場合が多い(山崎他, 2012).このような電力機器の絶縁性能を確保するためには,

\footnotetext{
No.14-00272 [DOI: 10.1299/transjsme.2014trans0291]

*1 正員, (株) 日立製作所日立研究所（テ312-0034 茨城県ひたちなか市堀口 832-2）

E-mail of corresponding author: miki.yamazaki.ra@hitachi.com
} 
界面における接着挙動を正確に把握することが重要な研究課題であり，マルチスケールを考慮した界面接着強度 を確保できる設計手法が必要である.

既報(山崎他, 2012), (山崎他, 2011a)，では樹脂モールド構造の界面およびインサート材の表面において，マル チスケールを考慮した界面接着強度評価手法を提案した。その中で，まず，ミクロスケールにおける金属表面粗 さが界面せん断強度に及ぼす影響をマクロスケールにおけるはく離試験により明らかにし，ミクロ・マクロスケ 一ルを連結させ，界面における材料固有の特性を表す接着強度指標を導き出した．次に，ミクロスケールにおけ る界面観察とナノスケールにおける分子動力学法に基づくシミュレーション(Dauber-Osguthorpe, 1988)を実施し 界面破壊エネルギーを求めた。 マクロスケールを考慮した接着強度指標とナノスケールにおける界面破壊エネル ギーを比較することにより界面はく離進展機構を明らかにし, 樹脂モールド構造おける界面の接着強度の評価お よび予測手法を提案した.

本報告では，実際の製品設計においてマルチスケールを考慮した樹脂と金属間の界面接着強度を確保できる設 計を実施するために，既報(山崎他, 2012)，(山崎他, 2010a), (Yamazaki, et al.,2011b)で金属表面粗さ測定により求 めた有効表面積と表面粗さとの関係と, 界面接着強度評価試験により求めた接着強度と表面粗さとの関係を用い て，マルチスケールを考慮した樹脂と金属間界面の接着強度を確保できる設計手法を提案する．また，実際の製 品設計における界面には繰り返し負荷が加わる場合が多いことを考慮し, 新たに表面粗さによる繰り返し負荷に 対する疲労強度と界面接着強度との関係を明らかにして, 本設計手法に反映する. 本設計手法により, 界面に加 わる繰り返し負荷に対して界面強度を確保するための部品の表面粗さ設定を図面段階で実施することができる. また, 組み合わせる材料毎に部品の寸法に応じた材料の表面粗さを定量的に決定することができ, 製品設計の信 頼性向上のためのマルチスケールを考慮した樹脂と金属間界面の疲労強度設計を行うことができる.

\section{2. マルチスケールを考慮した樹脂と金属間界面の接着強度を確保できる設計手法}

本章では実際の製品設計において界面接着強度を確保できる設計を実施するために，既報(山崎他，2012），(山 崎他, 2010a), (Yamazaki, et al., 2011b)で述べた有効表面積と表面粗さとの関係と, 接着強度と表面粗さとの関係を 用いて，マルチスケールを考慮した樹脂と金属間界面の接着強度を確保できる設計手法を提案する. 本設計手法 は, 界面接着強度に及ぼす設計因子を求めることで, 界面に加わる負荷に対して界面強度を確保するための部品 の表面粗さの設定を図面段階で実施することができる．また，組み合わせる材料毎に部品の寸法に応じて材料の 表面粗さを定量的に決定することができる.

\section{$2 \cdot 1$ 界面接着強度に影響を及ぼす設計因子}

金属と樹脂間界面の最大せん断力に及ぼす影響を設計因子毎に把握するために，界面に働く力について検討す る. 界面に沿ってはく離させるためのせん断力 $f_{s}$ は, 既報(山崎他, 2009), (Yamazaki, et al.,2010b)で提案した接着 係数 $\mathrm{B}$ と摩擦係数 $\mu$ にる接着強度指標 $(\mu+\mathrm{B})$, 残留応力による面圧 $\sigma_{\mathrm{pm}}$, 有効面積 $A_{e}$ を用いて式(1) と表わされる. なお, 接着強度指標 $(\mu+B)$ はマクロスケールのはく離試験による接着強度とナノスケールにおける分子動力学に基 づくシミュレーションによる界面破壊エネルギーを比較することにより, 界面はく離進展機構を明らかにし導き 出した材料固有の接着特性を表す指標である.

一方，表面粗さによる樹脂と金属間の界面のはく離せん断力は，凹凸界面の形状に加わる力の方向を考慮する 必要がある. 界面形状を考慮すると界面はく離は界面に沿ってではなく界面に垂直方向にはく離する，つまり， 界面の表面粗さによってマクロに結合の解離が起こり，はく離が進展することになる。これらのはく離進展特性 については Persson ら(Persson, 2001), (Persson, 2006), (Yang and Persson, 2008)も同様の指摘をしている.

凹凸界面のはく離時の最大せん断力を $f_{\text {smax-ra }}$ とすると， $f_{\text {smax-ra }}$ は凹凸界面の斜面と垂線の接触角 $\theta$ により, $f_{\text {smax-ra }}=f_{s} \cos \theta$ となる. したがって, 表面粗さがある場合の最大せん断力は, $f_{\text {smax-ra }}=(\mu+\mathrm{B})\left(\sigma_{\mathrm{pm}} A_{e} \cos \theta\right)$ と表わされる が，既報(山崎他，2012)で検討した金属表面粗さ $0.2 \mathrm{a} ， 5.0 \mathrm{a} ， 12.5 \mathrm{a}$ の接触角はそれぞれ，3.9，4.9，7.5であり， 式(1)における影響は小さいことから，本報告では式(1)を用いる.

$$
f_{s \max -r a}=(\mu+B)\left(\sigma_{\mathbf{p m}} A_{e}\right)
$$


また，残留応力 $\sigma_{\mathrm{pm}}$ は組み合わせ円筒の焼きばめ理論に基づく半径方向に加わる接触面圧として式(2)により求 めることができる．金属表面粗さの変動により樹脂内径の微小な変動はあるが，式(2)に示すように残留応力 $\sigma_{\mathrm{pm}}$ は金属表面粗さの変動による影響が小さい設計パラメータである.

$$
\sigma_{p m}=\frac{\delta}{2 R_{1}\left\{\frac{R_{3}^{2}+R_{1}^{2}}{E_{1}\left(R_{1}^{2}-R_{3}^{2}\right)}+\frac{R_{1}^{2}+R_{2}^{2}}{E_{2}\left(R_{2}^{2}-R_{1}^{2}\right)}+\frac{1}{E_{2} \nu_{2}}-\frac{1}{E_{1} v_{1}}\right\}}
$$

ここで， $R_{1}$ は金属円筒の外半径， $R_{2}$ は樹脂円筒の外半径であり， $R_{3}$ は金属円筒の内半径である. $E_{1}$ と $E_{2}$ はそれ ぞれ金属と樹脂のヤング率である。 $v_{1}$ と $v_{2}$ はそれぞれ金属と樹脂のポアソン比である．また， $\delta$ は焼きばめ代で あり，樹脂の内径の変位である．樹脂の内径の変位 $\delta$ は両材料の線膨張係数差x温度差x樹脂内径で求まる.

既報(山崎他, 2012)，(山崎他, 2010a)，(Yamazaki, et al.,2011b)で行った界面はく離試験により得られたCu，SUS の表面粗さをそれぞれ $0.2 \mathrm{a} ， 5 \mathrm{a} ， 12.5 \mathrm{a}$ に加工した場合の最大せん断力 $f_{\text {smax } r a}$ と最大摩擦力 $f_{\text {finax } r a \mathrm{z}}$ を表 1 に示寸.はく 離せん断力の挙動は試験初期の変位が小さいときにせん断力が急激に増大した後, 急激に減少する.この試験初 期のピーク值が最大せん断力 $f_{\text {smax ra }}$ すなわち接着界面のせん断強度の限界值を表わす.ピーク值発生後は界面全面 にはく離が生じ，はく離が生じた後は接着力(結合力)が解放され，金属と樹脂間は接触界面となり金属円柱は摩 擦力によってすべっていて, 押し出されるとともに接触面積が減少し，接触面積の減少に伴い金属と樹脂間の摩 擦力は低下する．最大摩擦力 $f_{\text {fnax-ra }}$ は金属円柱がす心゙り出す直前の摩擦力を表す.

式(1)に示寸界面に加わる最大せん断力 $f_{\text {smax } r a}$ と面圧力 $\sigma_{\mathrm{pm}} A_{e}$ の関係を図1に示す. 図1はCu，SUSにおいて表面粗 さ0.2a，5.0a，12.5aの3種類におけるそれぞれ点をプロットして比較している. 面圧力 $\sigma_{\mathrm{pm}} A_{e}$ はどの表面粗さにおい てもSUSの方がCuより大きい. これは残留応力 $\sigma_{\mathrm{pm}}$ と有効表面積 $A_{e}$ がCuよりSUSの方が大きいためである. しかし,

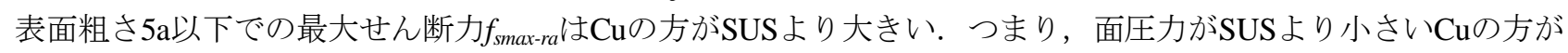
SUSより界面における材料固有の接着特性が良いことを示している. したがって, 表面粗さが小さい時は有効表 面積 $A_{e}$ にる界面強度への影響よりも接着係数Bによる界面強度への影響が大きいと考えられる. また, 図に示 すように最大せん断力 $f_{\text {smax }-r a}$ と面圧力 $\sigma_{\mathrm{pm}} A_{e}$ の関係は比例関係である. したがって, 面圧力が加わる条件の上で式(1) が成り立つことが図1によってわかる. また，界面接着強度は表す最大せん断力 $f_{\text {smax }-r a}$ と面圧力 $\sigma_{\mathrm{pm}} A_{e}$ の関係を示す 図1のそれぞれの3つの点を結んだ傾きはそれぞれの接着強度の指標 $(\mu+\mathrm{B})$ を表わすことがわかる.ここで摩擦係数 $\mu$ は表面粗さによって変動する因子であるが, 接着係数Bは材料固有の接着特性を表わすことから表面粗さの変動 に影響を受けないと考えられる.

このように表面粗さの変動に影響を受けない接着係数Bは, 材料間の固有性質(原子レベルでの引き寄せる強さ) による接着特性を表す指標であると考えられる，また，摩擦係数 $\mu$ は表面粗さの増加とともに増加する傾向があ るが, 表面粗さ零のときの理想状態での摩擦係数 $\mu$ を考えると, 材料間の固有性質による接着特性を表す指標で あると考えられる，接着界面強度を確保寸るためには，有効接着面積を増加させるとともに接着係数が大きくな る材料の組み合わせが必要であることがわかる，したがって，界面接着強度に主な影響及ぼす設計因子は有効接 着面積 $A_{e}$ と接着強度の指標 $(\mu+\mathrm{B})$ になると考えられる.

Table 1 Comparison of maximum shearing forces and maximum frictional forces

\begin{tabular}{|c|c|c|c|c|}
\hline \multirow{3}{*}{$\begin{array}{c}\text { Surface } \\
\text { roughness } \\
(\mu \mathrm{m})\end{array}$} & \multicolumn{4}{|c|}{ Experimental value } \\
\hline & \multicolumn{2}{|c|}{$\mathrm{Cu}$} & \multicolumn{2}{|c|}{ SUS } \\
\hline & $\begin{array}{c}f_{\text {smax }-r a} \\
(\mathrm{kN})\end{array}$ & $\begin{array}{c}f_{\text {fmax }}-r a \\
(\mathrm{kN})\end{array}$ & $\begin{array}{c}f_{\text {smax }-r a} \\
(\mathrm{kN})\end{array}$ & $\begin{array}{c}\text { ffmax }-r a \\
(\mathrm{kN})\end{array}$ \\
\hline 0.2 & 20.0 & 6.3 & 13.0 & 6.0 \\
\hline 5.0 & 32.8 & 10.5 & 30.0 & 14.5 \\
\hline 12.5 & 47.0 & 46.9 & 51.0 & 49.0 \\
\hline
\end{tabular}

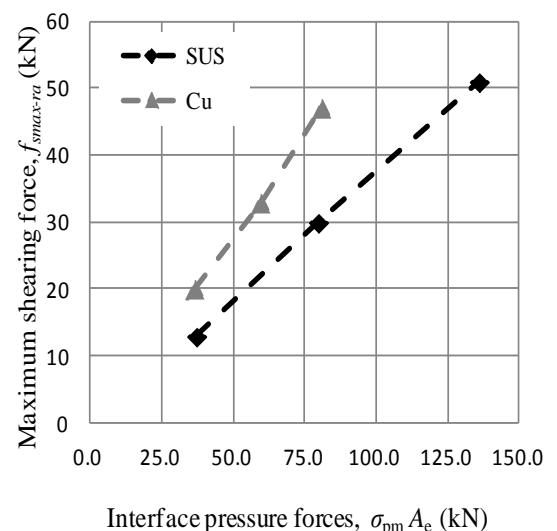

Fig. 1 Relationship between maximum shearing forces and interface pressure forces 


\section{$2 \cdot 2$ 樹脂と金属間界面の設計手法}

樹脂モールド構造における樹脂と金属間界面に加わる負荷 $f_{\text {load }}$ に対して, 界面強度を確保するための設計手法を 提案する.

有効表面積と表面粗さとの関係を求めるために既報(山崎他, 2012)ではミクロスケールの金属の表面粗さの凹 凸をレーザー顕微鏡(Keyence VK-9510)により測定し，金属表面の有効表面積を求めた。また，測定部位が円柱表 面の微小表面であることから，円周方向の測定長さと軸方向の測定長さによる見かけ上の表面積は $A_{0}$ と仮定し， 有効表面積 $A_{\mathrm{e}}$ と見かけ上の表面積 $A_{0}$ の面積比を有効面積の倍率 $e$ と定義した. Cuとステンレス鋼(SUS304, 以下SUS と略す)のそれぞれの表面粗さ0.2a，5.0a，12.5a毎の有効面積の倍率 $e$ 算出し，図2に示す有効表面積と表面粗さ との関係を求めた.

このように有効表面積 $A_{\mathrm{e}}$ と見かけ上の表面積 $A_{0}$ の面積比を有効面積の倍率 $e$ と定義すると, 式(1)は次の式(3)に 表すことができる.

$$
f_{s \max -r a}=(\mu+B)\left(\sigma_{\mathbf{p m}} A_{0} e\right)
$$

また，式(3)を有効面積の倍率eに対して変換し，界面強度を確保するためには $f_{\text {load }} \leq f_{\text {smax }- \text { ra }}$ であることを考慮す ると有効面積の倍率 $e$ は式(4)のように表される. 界面の接着強度を確保するための有効面積の倍率 $e$ は，安全率な どを考慮した要求される負荷 $f_{\text {load }}$, 図面寸法による金属の見かけ上の表面積 $A_{0}$, 式(2)による金属と樹脂間の残留応 力 $\sigma_{\mathrm{pm}}$, 図1による傾きつまり，金属の接着強度指標 $(\mu+B)$ を求め, 式(4)に代入することで求められる.

$$
e \geq \frac{f_{\text {load }}}{(\mu+B)\left(\sigma_{\mathbf{p m}} A_{0}\right)}
$$

次に, 式(4)によって求められる有効面積の倍率 $e$ を図2に照らし合わせて, 界面強度を確保するための表面粗さ を決定することができる，たとえば，式(4)によって得られた有効表面積比が $e=6$ の場合, 図 2 に照らし合わせると $\mathrm{Cu}$ の部品は12.5a以上の表面粗さとSUSの部品は5a以上の表面粗さの設定が必要であることがわかる.

界面接着強度を確保するための表面粗さ設計手法の手順を図 3 に示す. 図 3 に示すように, 界面接着強度に及 ぼす設計因子 $A_{0}, \sigma_{\mathrm{pm}},(\mu+\mathrm{B})$ を求めることで, 界面に加わる負荷に対して界面強度を確保するための部品の表面 粗さの設定を図面段階で実施することができる。また，組み合わせる材料毎に図面の部品の寸法に応じて材料の 表面粗さを定量的に決定することができる。 さらに，図 1, 図 2 は Cuと SUS における接着強度の設計因子であ るが，これらの設計因子を材料毎にデータベース化することにより，さらに効率よい設計が実施できる.

一方，式(4)における界面に加わる負荷 $f_{\text {load }}$ は実際の製品では繰り返し加わることから疲労強度を考慮しなけれ ばならない，そこで，新たに表面粗さによる繰り返し負荷に対する疲労強度と界面接着強度との関係を明らかに して，図 3 の設計手法に反映する必要がある.

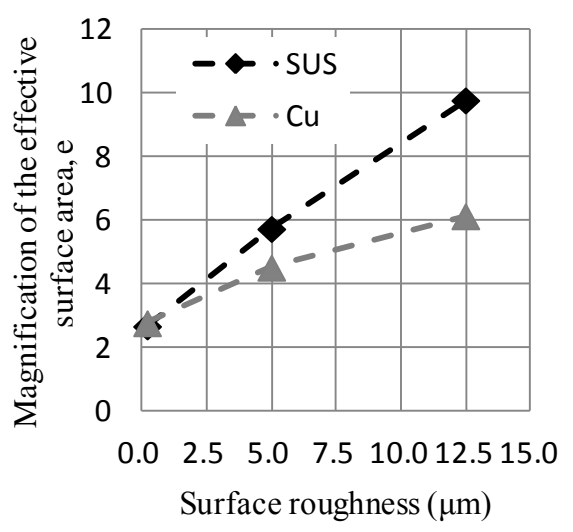

Fig. 2 Relationship between magnification of effective area and surface roughness

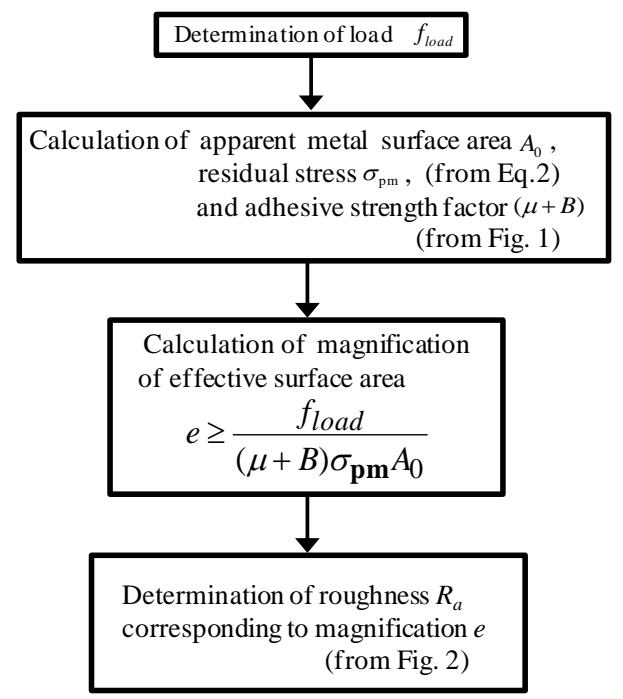

Fig. 3 Procedure of deign method of interface adhesive strength shearing forces and pressure forces 


\section{3. 繰り返し負荷に対する接着界面疲労強度設計}

前章では有効表面積と表面粗さとの関係と，接着強度指標と表面粗さとの関係を用いて，マルチスケールを考 慮した樹脂と金属間界面の接着強度を確保できる設計手法を提案した。しかし，電力機器などは実稼働時には繰 り返し負荷が界面に加わる場合がほとんどである，したがって，実際の製品設計において界面接着強度を確保す るためには，金属表面の粗さに対する繰り返し負荷時の接着界面の疲労強度を評価することが必要である.

本章では実際の製品設計における界面に加わる繰り返し負荷を考慮し，新たに表面粗さによる繰り返し負荷に 対する疲労強度と界面接着強度との関係を明らかにして，前章の図 3 に示寸設計手法に反映する.

\section{$3 \cdot 1$ 繰り返し負荷に対する接着界面疲労強度試験の要素試験体}

実験体製作には図 4(a)に示寸金属円柱(直径 $37 \mathrm{~mm}$ ，高さ $30 \mathrm{~mm}$ ) と樹脂の厚さが $10 \mathrm{~mm}$ になるように製造した 金型を用いる。また，図 4(a)に示すように金型中に液状のエポキシ樹脂を注入し真空脱泡を行い，温度上昇によ る硬化反応で金属円柱と樹脂が一体となり金型から離型され，図 4(b)の試験体が製作される．エポキシ樹脂のよ うな熱硬化型樹脂モールドは，樹脂が硬化するときに起こる体積変化，および樹脂と金属の熱膨張係数の差異に よるひず夕に起因する残留応力 $\left(\sigma_{\mathrm{pm}}\right)$ が面圧として図 5(a)のように内部界面に働く，その内部界面の金属と樹脂間 の状態をレーザー顕微鏡で観察した写真を図 5(b)に示す．金属と樹脂間の界面は金属表面の切削痕による周期的 凹凸に樹脂が流れ込み硬化した状態となっている．金属円柱には無酸素銅(C1011，以下 $\mathrm{Cu}$ と略す)とステンレス (SUS304，以下 SUS と略す)を用い，それぞれの材料の表面粗さを算術平均粗さ Ra(JIS B 0601-1994)で 0.2a，5.0a， $12.5 \mathrm{a}$ の 3 種類に加工した. 表面の加工には旋盤を利用した. 3 種類の表面粗さとも金属円柱軸の回転速度は同じ にして, 加工工具の送り速度を表面粗さ 3 種類毎に変更することで, 加工面の粗さ(表面凹凸の高さ)を調整した.

\section{$3 \cdot 2$ 繰り返し負荷に対する接着界面疲労強度試験方法}

図4の要素試験体を用いて, 表面粗さによる界面強度と繰り返し負荷が加わる場合の接着界面の疲労強度試験を 行う.要素試験体が設置されている試験状況を図6に示す.試験機は島津製作所製電気油圧サーボ型疲労試験機(最 大容量 $\pm 100 \mathrm{kN}$ ）を使用した。また，計測器は共和電業製センサインタフェース一式(PCD-320A)を使用した.

試験方法は図 5 に示寸ように要素試験体を可動治具に押し込み，可動治具が上下に動くことによって，要素試 験体の金属円柱部位に固定治具 $(\phi 36 \mathrm{~mm}$ の柱状になっている)が接触し, 樹脂と金属の界面に繰り返し負荷を加 える. 可動治具(下側)には, $\phi 57 \mathrm{~mm}$ (寸法公差 $+0.5 /+0.3)$, 深さ $5 \mathrm{~mm}$ の溝が設けられ, この溝に樹脂を固定する. 溝の下側に $\phi 38 \mathrm{~mm}$ の穴があり，押し込まれた円柱形金属が貫通するようになっている.

試験環境は室温・大気中，負荷様式は軸力圧縮，制御方法は荷重制御，負荷波形は正弦波(片振り，応力比 $\mathrm{R} \doteqdot$ $0.1)$, 試験速度は $10 \mathrm{~Hz}$, 最大繰返し数は $2.0 \times 10^{5}$ 回以上と設定した．なお，本報告での最大繰返し数は電力機器 の実製品設計に要求される繰返し数である.また, 試験終了条件は要素試験体の円柱形金属から樹脂が剥離した 時点, もしくは, 最大繰返し数に到達した時点とした.

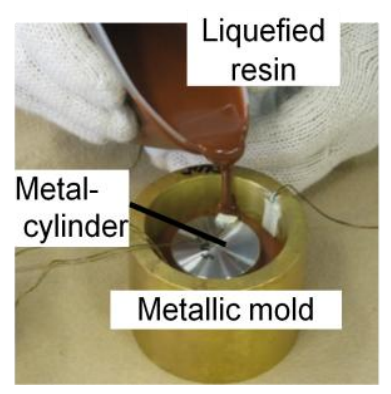

(a) Stress field

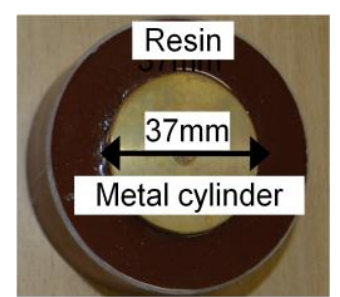

(b) Interface observed by microscope

Fig. 4 Test piece by process of resin-mold

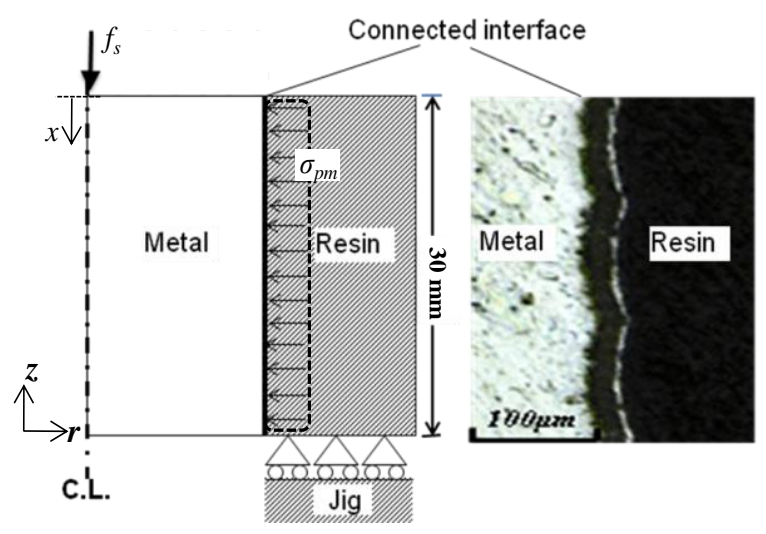

(a) Pouring of resin (b) Test piece Fig. 5 Z-axis symmetry cross section of test piece 


\section{$3 \cdot 3$ 絽り返し負荷に対する接着界面疲労強度評価}

繰り返し負荷によるせん断力 $\Delta f_{s}$ と破断繰り返し数 $N_{f}$ との関係を図 7, 図 8 に示寸. 図 7 は表面粗さ $0.2 \mathrm{a}, 5.0 \mathrm{a}$, 12.5a の 3 種類に加工した SUS の場合を表し, 図 8 は表面粗さ 0.2a, 5.0a, 12.5a の 3 種類に加工した Cu の場合を 表す．せん断力 $\Delta f_{s}$ は繰り返し員荷によるせん断力の大きさを表す. 図 7 と図 8 ともに，表面粗さを大きくして いくと疲労限度のせん断力 $f_{w}$ も大きくなっていることがわかる. 通常の疲労限度のせん断力は $10^{6}$ 回以上の負荷 を繰り返しても疲労破壊に至らない值とするが，本報告での疲労限度のせん断力 $f_{w}$ は最大繰返し数 $2.0 \times 10^{5}$ 回以 上繰り返しても疲労破壊に至らない值とする.

これらの繰り返し負荷に対する表面粗さと疲労限度の関係は表 1 に示寸静的負荷による表面粗さと最大せん断 力の関係と同じ傾向で, 表面粗さが増加する程疲労限度は増加する. SUS と Cu それぞれの場合の静的負荷によ る最大せん断力と繰り返し負荷による疲労限度のせん断力の比較を表 2 に示す. いずれの表面粗さにおいても疲

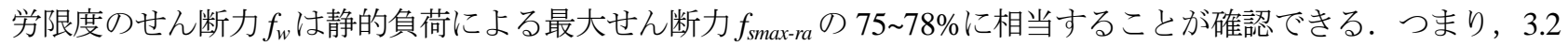
節で示した繰り返し負荷を与えた場合において，それぞれの表面粗さにおいて静的負荷の 75\%以下のせん断力で あれば，負荷を繰り返しても疲労破壊に至らないことが推測できる.

以上の結果から，図3に示寸マルチスケールを考慮した樹脂と金属間界面の接着強度を確保できる設計手法に 反映すると, 想定される負荷 $f_{\text {load }}$ に対して設計負荷 $f_{\text {load }} \times 1.33$ に設定することで繰り返し負荷に対しても，界面強 度を確保するための部品の表面粗さ設定を図面段階で実施することができる．また，組み合わせる材料毎に部品 の寸法に応じた材料の表面粗さを定量的に決定することができ，製品設計の信頼性向上のためのマルチスケール を考慮した樹脂と金属間界面の疲労強度設計を行うことができる.

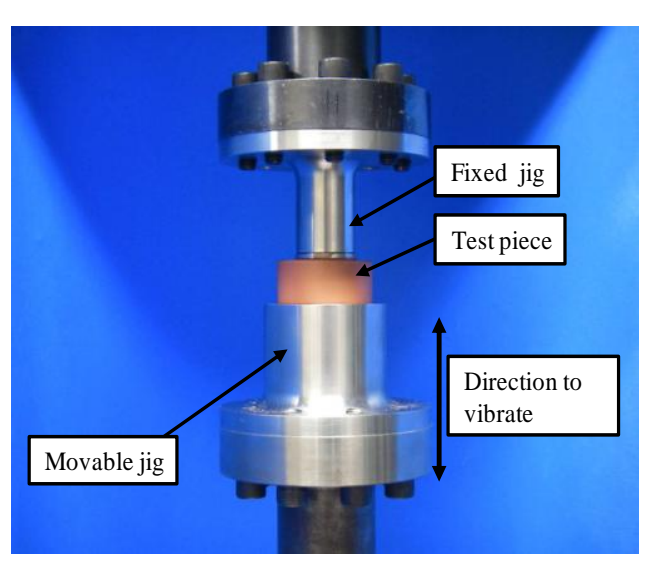

Fig.6 Setting to testing equipment of test piece

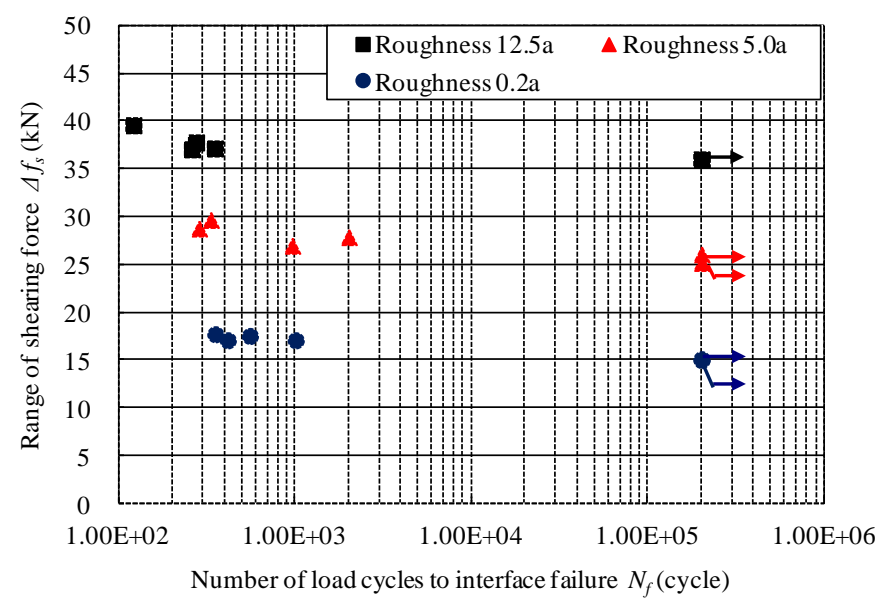

Fig.8 Relation between range of shearing force and number of load cycles $(\mathrm{Cu})$

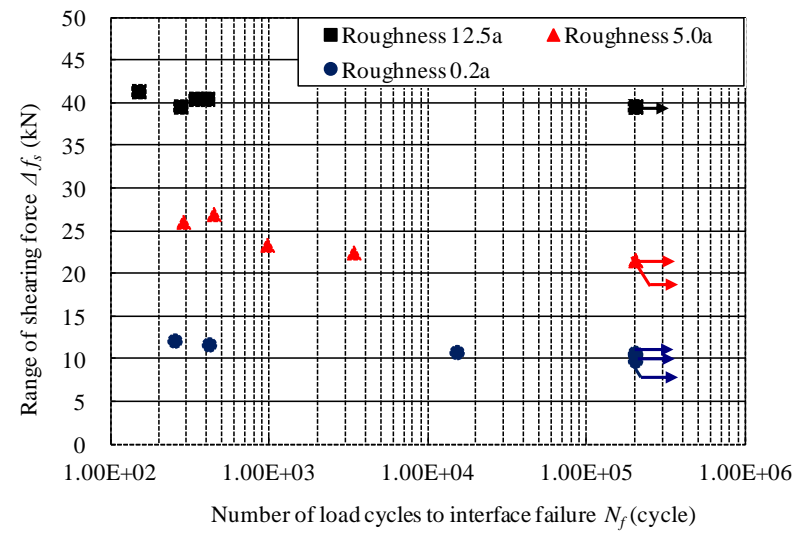

Fig.7 Relation between range of shearing force and number of load cycles (SUS)

Table 2 Comparison of maximum shearing force and shearing force of fatigue limit

\begin{tabular}{c|c|c|c|c|c|c}
\hline \multirow{2}{*}{$\begin{array}{c}\text { Roughness } \\
(\mu \mathrm{m})\end{array}$} & \multicolumn{2}{|c|}{$\begin{array}{c}\text { Maximum } \\
\text { shearing force }\end{array}$} & \multicolumn{2}{c|}{$\begin{array}{c}\text { Shearing force of } \\
\text { fatigue limit }\end{array}$} & \multicolumn{2}{c}{ Ratio to dead load } \\
\cline { 2 - 7 } & $\mathrm{Cu}$ & $\mathrm{SUS}$ & $\mathrm{Cu}$ & $\mathrm{SUS}$ & $\mathrm{Cu}$ & $\mathrm{SUS}$ \\
\hline \hline $\begin{array}{c}f_{\text {smax-ra }} \\
(\mathrm{kN})\end{array}$ & $\begin{array}{r}f_{\text {smax-ra }} \\
(\mathrm{kN})\end{array}$ & $\begin{array}{c}\Delta f_{w} \\
(\mathrm{kN})\end{array}$ & $\begin{array}{c}\Delta f_{w} \\
(\mathrm{kN})\end{array}$ & $\begin{array}{c}\left(\Delta f_{w} / f_{\text {smax }-r a}\right) \\
\times 100(\%)\end{array}$ & $\begin{array}{c}\left(\Delta f_{w} / f_{\text {smax }-r a}\right) \\
\times 100(\%)\end{array}$ \\
\hline 0.2 & 20.0 & 13.0 & 15.0 & 9.8 & 75 & 75 \\
\hline 5.0 & 32.8 & 30.0 & 25.0 & 23.0 & 76 & 77 \\
\hline 12.5 & 47.0 & 51.0 & 36.0 & 39.6 & 77 & 78 \\
\hline
\end{tabular}

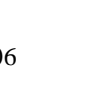

.

(2)

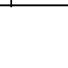


今後の課題として樹脂モールド構造における接着界面の静的な破壊と疲労的な破壞の破壊様式の検討があげら れる．静的な界面破壊の場合は既報(山崎他，2012)，(山崎他, 2011a)の方で走查型電子顕微鏡(Scanning Electron Microscope，SEM)を用いた金属と樹脂間の界面形状の観察写真および解析により, 界面の表面粗さによってマク ロに結合の解離(モードI 型)が起こり，それによりはく離が生じることを示している．これは繰り返し負荷を与 える疲労的な破壊の場合も同様なはく離進展特性を示していると推測される．また，本報告で示した界面強度評 価は初期欠陥を仮定した界面き裂に基づく界面強度評価ではない。しかし，界面破壊が脆性的な破壊であること と, 界面疲労破壞も荷重負荷部の界面におけるき裂発生に対応していると推測すると, 界面き裂に基づく界面強 度を基準強度に用いることができると考察できる．今後さらに研究を重ねて別報で報告する．

\section{4. 結言}

実際の製品設計において界面接着強度を確保できる設計を実施するために，既報(山崎他，2012)，(山崎他， 2010a)でミクロスケールにおける金属表面粗さ測定により求めた有効表面積と表面粗さとの関係と，マクロスケ 一ルを考慮した界面接着強度評価試験により求めた接着強度と表面粗さとの関係を用いて，マルチスケールを考 慮した樹脂と金属間界面の接着強度を確保できる設計手法を提案した．本設計手法によって，部品の表面粗さ設 定を図面段階で実施することができると共に，組み合わせる材料毎に部品の寸法に応じて材料の表面粗さを定量 的に決定することが可能となり，界面に加わる負荷に対して界面接着強度を確保する構造設計ができることを示 した.

また，実際の製品における界面には繰り返し負荷が加わる場合が多いことを考慮し，新たに表面粗さによる繰 り返し負荷に対する疲労強度と界面接着強度との関係を明らかにした. SUS と $\mathrm{Cu}$ それぞれの場合の静的負荷に よる最大せん断力と繰り返し負荷による疲労限度のせん断力の比較を行い，いずれの表面粗さにおいても疲労限 度のせん断力 $f_{w}$ は静的負荷による最大せん断力の 75 78\%に相当することが確認できた。したがって，本報告に おける繰り返し負荷を与えた場合，それぞれの表面粗さにおいて静的負荷の $75 \%$ 以下のせん断力であれば，負荷 を繰り返しても疲労破壊に至らないことが確認できた．以上の結果からマルチスケールを考慮した樹脂と金属間 界面の接着強度を確保できる設計手法における設計負荷を想定される負荷の 1.33 倍に設定することで繰り返し負 荷に対しても信頼性が高い接着界面強度を確保できることがわかった.

\section{文献}

Atkinson, J. R. and Cicek, R. Z., Silane cross-linked polyethylene for prosthetic applications. part I. certain physical and mechanical properties related to the structure of the material, Biomaterials, Vol. 4 (1983a), pp. 267-275.

Atkinson, J. R. and Cicek, R. Z., "Silane cross-llinked polyethylene for prosthetic applications. part II. creep and wear behavior and a preliminary moulding Test, Biomaterials, Vol. 4 (1983b), pp. 326-335.

Dauber-Osguthorpe, P., Roberts, V. A., Wolff, D. J. J., Genest, M. and Hagler, A. T., Structure and energetics of ligand binding to proteins E. coli dihydrofolate reductase-trimethoprim, a Drug-Receptor System, Proteins: Structure, Function and Genetics, Vol. 4 (1988), pp. 31-47.

Okamoto, T., Shibuya M., Takahashi, T., Mizutani, Y. and Takahashi, T., Proposal of all solid insulated substation for future substation, IEEE 7th Intern. Conf. Properties and Application of Dielectric Materials (ICPADM), Vol. S22-4 (2003), pp. 1190-1193.

Persson, B. N. J., Contact mechanics for randomly rough surfaces, Physical Review Letters (2006), pp. 201-227.

Persson, B. N. J., Theory of rubber friction and contact mechanics, Journal of Chemical Physics, Vol. 115, No. 8 (2001), pp.3840-3861.

Sato, J., Sakaguchi, O., Kubota, N., Makishima, S., Kinoshita, S., Shioiri, T., Yoshida, T., Miyagawa, M., Homma, M. and Kaneko, E., New technology for medium voltage solid insulated switchgear, IEEE/PES Transmission and Distribution Conference and Exhibition: Asia Pacific, Vol. 3 (2002), pp.1791-1796.

Wong, W. K. and Varral, D. C., Role of molecular structure on the silane crosslinking of polyethylene: the importance of resin molecular structure change during silane grafting, Polymer, Vol. 35 (1994), pp. 5447-5452. 
Yamazaki, M., Izumi, S. and Sakai, S., New method of adhesion / friction analysis for resin molded structures and its application to air-Insulated rod, Journal of Engineering Materials and Technology, Vol. 4, No. 4 (2010b), pp.533-544.

Yamazaki, M., Iwasaki, T., Izumi, S. and Sakai, S., Atomic-level modelling for predicting interface strength in resin molded structures, Journal of Engineering Materials and Technology, Vol. 5, No. 1 (2011b), pp.54-63.

Yang, C. and Persson, B. N. J., Contact mechanics: contact area and interfacial separation from small contact to full contact, Journal of Physics, Condensed Matter, Vol. 20 (2008), pp. 215214_1-215214_13.

山崎美稀, 岩崎富生, 樹脂モールド構造における金属と樹脂間界面の接着強度評価，日本機械学会論文集 $\mathrm{A}$ 編， Vol.78, No.790 (2012), pp.855-864.

山崎美稀, 岩崎富生, 樹脂モールド構造におけるセラミックスと樹脂間の接着界面強度評価, 日本機械学会論文 集 A 編, Vol.77, No.774 (2011a),pp.345-351.

山崎美稀, 岩崎富生, 泉聡志, 酒井信介, 樹脂モールド構造内部界面における界面接着強度の予測への原子レベル モデリングの適用，日本機械学会論文集 A 編，Vol. 76，No. 770 (2010a)，pp.1303-1309.

山崎美稀, 泉聡志, 酒井信介, 樹脂モールド構造のための接着・摩擦解析手法の開発と気中絶縁ロッドへの応用, 日本機械学会論文集 A 編, Vol.75, No.756 (2009), pp.974-980.

山崎美稀, マルチスケールを考慮した表面・界面の設計工学とその応用, 日本機械学会 2013 年度年次大会, K12300 (2013), pp.1-5.

\section{References}

Atkinson, J. R. and Cicek, R. Z., Silane cross-linked polyethylene for prosthetic applications. part I. certain physical and mechanical properties related to the structure of the material, Biomaterials, Vol. 4 (1983a), pp. 267-275.

Atkinson, J. R. and Cicek, R. Z., Silane cross-llinked polyethylene for prosthetic applications. part II. creep and wear behavior and a preliminary moulding test, Biomaterials, Vol. 4 (1983b), pp. 326-335.

Dauber-Osguthorpe, P., Roberts, V. A., Wolff, D. J. J., Genest, M. and Hagler, A. T., Structure and energetics of ligand binding to proteins E. coli dihydrofolate reductase-trimethoprim, a Drug-Receptor System, Proteins: Structure, Function and Genetics, Vol. 4 (1988), pp. 31-47.

Okamoto, T., Shibuya M., Takahashi, T., Mizutani, Y. and Takahashi, T., Proposal of all solid insulated substation for future substation, IEEE 7th Intern. Conf. Properties and Application of Dielectric Materials (ICPADM), Vol. S22-4, (2003), pp. 1190-1193.

Persson, B. N. J., Contact mechanics for randomly rough surfaces, Physical Review Letters (2006), pp. $201-227$.

Persson, B. N. J., Theory of rubber friction and contact mechanics, Journal of Chemical Physics, Vol. 115, No. 8 (2001), pp.3840-3861.

Sato, J., Sakaguchi, O., Kubota, N., Makishima, S., Kinoshita, S., Shioiri, T., Yoshida, T., Miyagawa, M., Homma, M. and Kaneko, E., New technology for medium voltage solid insulated switchgear, IEEE/PES Transmission and Distribution Conference and Exhibition: Asia Pacific, Vol. 3 (2002), pp.1791-1796.

Wong, W. K. and Varral, D. C., Role of molecular structure on the silane crosslinking of polyethylene: the importance of resin molecular structure change during Silane grafting, Polymer, Vol. 35 (1994), pp. 5447-5452.

Yamazaki, M. and Iwasaki, T. , Evaluating strength of adhesive interface between metal and resin in resin-molded structures, Transactions of the Japan Society of Mechanical Engineers, Series A, Vol.78, No.790 (2012), pp.855-864 (in Japanese).

Yamazaki, M. and Iwasaki, T., Evaluating strength of adhesive interface between ceramic and resin in resin-molded structures, Transactions of the Japan Society of Mechanical Engineers, Series A, Vol.77, No.774 (2011a), pp.345-351 (in Japanese). 
Yamazaki, M., Iwasaki, T., Izumi, S. and Sakai, S., Atomic-level modelling for predicting interface strength in resin molded structures, Transactions of the Japan Society of Mechanical Engineers, Series A, Vol. 76, No. 770 (2010a), pp.1303-1309 (in Japanese).

Yamazaki, M., Izumi, S. and Sakai, S., New method of adhesion/friction analysis for resin molded structures and Its application to air-insulated rod, Transactions of the Japan Society of Mechanical Engineers, Series A, Vol.75, No.756 (2009), pp.974-980 (in Japanese).

Yamazaki, M., Design Engineering and Its Application of Surface and Interface on Multiple Scales, Proceedings of the JSME annual meeting, K12300 (2013), pp.1-5 (in Japanese).

Yamazaki, M., Izumi, S. and Sakai, S., New method of adhesion / friction analysis for resin molded structures and its application to air-insulated rod, Journal of Engineering Materials and Technology, Vol. 4, No. 4 (2010b), pp.533-544.

Yamazaki, M., Iwasaki, T., Izumi, S. and Sakai, S., Atomic-level modelling for predicting interface strength in resin molded structures, Journal of Engineering Materials and Technology, Vol. 5, No. 1 (2011b), pp.54-63.

Yang, C. and Persson, B. N. J., Contact Mechanics: Contact area and interfacial separation from small contact to full contact, Journal of Physics: Condensed Matter, Vol. 20 (2008), pp. 215214_1-215214_13. 